This item was submitted to Loughborough's Research Repository by the author.

Items in Figshare are protected by copyright, with all rights reserved, unless otherwise indicated.

\title{
European responses to US diplomacy: 'special relationships', transatlantic governance and world order
}

PLEASE CITE THE PUBLISHED VERSION

http://dx.doi.org/10.1163/9789004214149

PUBLISHER

(C) Brill

VERSION

AM (Accepted Manuscript)

LICENCE

CC BY-NC-ND 4.0

\section{REPOSITORY RECORD}

Smith, Michael H.. 2019. "European Responses to US Diplomacy: 'special Relationships', Transatlantic Governance and World Order”. figshare. https://hdl.handle.net/2134/15008. 
This item was submitted to Loughborough's Institutional Repository (https://dspace.lboro.ac.uk/) by the author and is made available under the following Creative Commons Licence conditions.

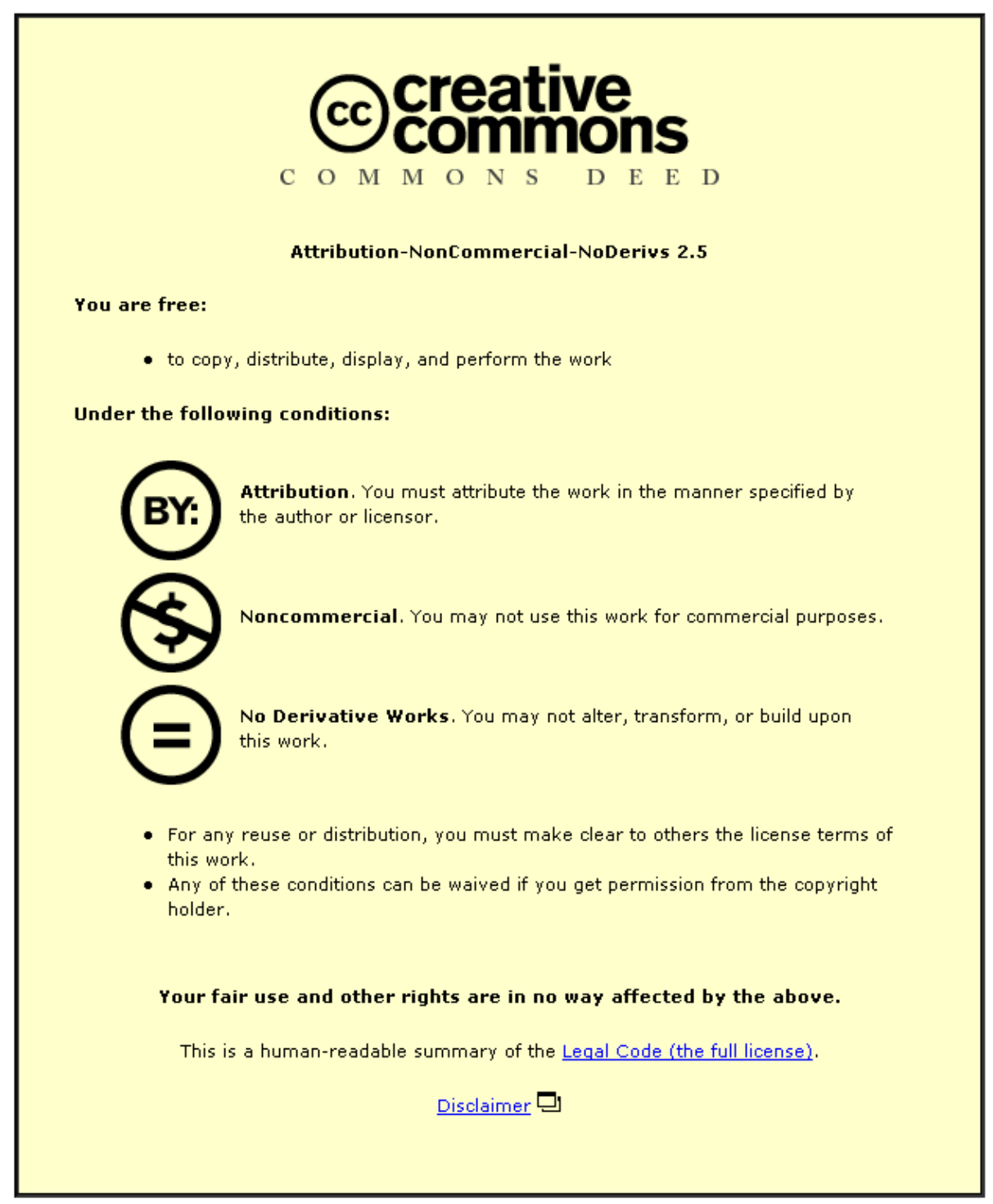

For the full text of this licence, please go to: http://creativecommons.org/licenses/by-nc-nd/2.5/ 


\title{
European Responses to US Diplomacy: 'Special Relationships', Transatlantic Governance and World Order
}

\begin{abstract}
Summary
This article explores the contrasting diplomacies of the United States and the European Union, drawing attention to the characteristics of the US as a 'warrior state' and the EU as a form of 'trading state' in which a complex and hybrid form of diplomacy is produced through the interplay of European and national foreign policies. It then pursues the argument that the interplay of US and EU diplomacies has generated an evolving EU-US diplomatic system, which in itself is hybrid and multi-dimensional. The article explores the context within which the EU-US diplomatic system has evolved and is evolving, and proposes three key patterns of diplomatic relations as the core of the system: 'special relationships' reflecting specific ties between the US and key EU Member States, 'transatlantic governance' reflecting the growth of transatlantic transactions and demands for their management, and 'world order diplomacy' centred on global governance institutions, patterns of intervention and crisis management. The article explores these patterns as they have manifested themselves during the George W Bush and Obama Presidencies, and concludes by asking whether the implementation of the Lisbon Treaty in the EU is likely to bring about significant change in the patterns of EU-US diplomacy.
\end{abstract}

\section{Keywords}

European Union; United States; diplomacy; special relationships; transatlantic governance; world order

\section{Introduction}

This article aims to explore the ramifications of two coexisting processes, which arguably reflect 'two worlds of diplomacy' represented by the European Union (EU) and the United States (US). On the one hand, it examines the challenges posed by US foreign policy and diplomacy, and tries to identify some of the constants around which successive US Administrations have fluctuated. In doing so, it makes the argument that US diplomacy is pervaded by the character of the US as a 'warrior state', which places a strong emphasis on sovereignty, state action and the use of force. 
In contrast, European diplomacy represents a distinctive hybrid. On the one hand, there is European diplomacy in its broad sense, encompassing the diplomacy of European countries, among them some significant if secondary 'powers', as well as patterns of collective European action. On the other hand, there is the diplomacy accompanying 'European foreign policy', centred on the European Union and reflecting the progress and limitation of the European integration project. The argument here is that both of these versions of 'European diplomacy' need to be taken into account, and that the hybrid characteristics of 'European diplomacy' are precisely the result of the interaction between these two strands of development.

The article argues that these coexisting and intersecting characteristics of US and European diplomacy have given rise to a hybrid 'EU-US diplomatic system' with a number of key characteristics and patterns of behaviour. This system is explored in more depth in terms of its impact during the George W Bush and Obama Presidencies, and in terms of developments in the EU after the implementation of the Lisbon Treaty in 2009. The article concludes by discussing the possibility that a new EU diplomatic system might transform the EU-US diplomatic system, and by linking the development of the EU-US system to broader developments in the field of diplomacy.

\section{The United States and Europe: Two Worlds of Diplomacy?}

A summary version of US diplomacy would certainly start from the central importance of strategy, and of 'grand strategy' in particular. US foreign policy discourse is characterised by attention to the building of a strategic framework 
in which vital interests are identified and strategic choices made in order to facilitate the pursuit of those interests. There is a long tradition in debates about US foreign policy of reference to the demands of grand strategy, and of the key significance surrounding the procurement of capabilities - especially military capabilities - with which to pursue $\mathrm{it}^{1}$. Not surprisingly, these debates lead to a focus on material capabilities and what has been termed 'hard power' in the pursuit of US foreign policy ambitions; indeed, it has also been argued by Joseph Nye and others that the focus on 'hard power' has led to a squandering of US 'soft power' resources, and that the need to restore balance in US policy demands a focus on 'smart power'2. Ultimately, this focus on grand strategy and 'hard power' means that there is an accompanying focus on the possibility (or indeed, the likelihood) of the use of force itself.

This focus on grand strategy, hard power and the likelihood of the use of force gives a very specific context for the development of US diplomacy. I would argue that this context has been apparent since the late $19^{\text {th }}$ century, and that it has given the US the general characteristics of a 'warrior state' ${ }^{3}$. The diplomacy of such a state is likely to be 'sovereignist', emphasising the autonomy of the state and the need to protect its national security, if necessary by the use of force. Where such a state musters dominant power

\footnotetext{
${ }^{1}$ See for example C Kupchan, The End of the American Era: US Foreign Policy and the Geopolitics of the Twenty-First Century (New York: Vintage, 2002); R. Lieber, The American Era: Power and Strategy for the $21^{\text {st }}$ Century (New York: Cambridge University Press, 2007). 2 J. Nye, Soft Power: The Means to Success in Foreign Policy (New York: Public Affairs, 2004); R. Armitage and J. Nye, CSIS Commission on Smart Power (Washington, DC: CSIS, 2007); T. Galen Carpenter, Smart Power: Toward a Prudent Foreign Policy for America (Washington, DC: Cato Institute, 2008)

${ }^{3}$ M. Smith, 'Between Two Worlds? The European Union, the United States and World Order',International Politics vol 41, no. 1, 2004, pp. 96-117; M. Smith, 'The European Union, the United States and Global Public Goods: Competing Models or Two Sides of the Same Coin?' in R. Whitman (ed) Normative Power Europe: Conceptual and Empirical Perspectives (London: Routledge).
} 
within the world arena, its diplomacy is also likely to rest upon assumptions of precedence and of the capacity to challenge the sovereignty of other, lesser powers. Diplomacy in such a context is also likely to be directed towards (or result in) the cultivation of client relationships and of dependencies, whether formal or informal. Given the presence of dominant power, it is also probable that diplomacy will be strongly results-orientated, with a focus on bargaining against a background of superior resources - although such a diplomacy does not guarantee the desired results, given the capacity of lesser powers to exploit specific contexts or to act collectively against the dominant power ${ }^{4}$. The presence of dominant power also implies that the calculus of diplomacy is likely to be affected; in other words, whether or not - or how much - to use diplomatic methods becomes a matter of political choice, rather than a necessity reflecting the need to negotiate even with one's sworn enemies. Such a pattern of diplomacy (broadly defined) has consequences for the pattern of diplomatic activity (narrowly defined): it is likely to circumscribe the influence of professional diplomats, to call into question the precedence of conventional diplomatic structures, and to engender at the very least suspicion and perhaps open resistance on the part of diplomatic partners.

No matter what the fluctuations in style and specific content, it might be argued, US foreign policy and diplomacy is consistently that of a 'warrior state'. It does not matter which President or Administration is at issue - the features will be there, modified by circumstances or by issues but never absent. Thus, diplomacy will be strongly conditioned by the evolution of the global balance of power (as understood in Washington), and will also respond

\footnotetext{
${ }^{4}$ M. Mandelbaum, The Case for Goliath: How America Acts as the World's Government in the $21^{\text {st }}$ Century (New York: Public Affairs, 2005).
} 
to domestic pressures, but will always manifest itself in the ways characteristic of a 'warrior state': sovereignist, shaped by grand strategy, admitting the possibility if not the probability of the use of force and centring on bargaining conditioned by the presence of dominant material power. Such a set of features is a stark contrast to - and a challenge to - more conventional approaches to US diplomatic practice. It challenges the role of the Department of State, it can lead to a centralisation of activity in the executive branch, and it tends to give a central role to the threat or the use of military force. It also constitutes a major challenge to European diplomacy.

From the hybrid nature of European diplomacy outlined earlier arises one of its key characteristics: complexity of preferences and strategies. Whereas in the US case it is possible to debate 'grand strategy', in the European case such a debate is difficult to initiate, let alone to pursue on a consistent basis. Whilst Sven Biscop and others have made valiant attempts to argue the need for a 'European grand strategy' ${ }^{5}$, it is very difficult to ignore the key obstacles to such a strategy. 'Europe' lacks a collective vision of the world - perhaps even of Europe itself - and lacks also the material resources and commitments from its constituent countries that would provide a basis for 'grand strategy'. The most significant EU statement of strategy, the European Security Strategy of 2003 , revised in 2008 , simply cannot refer to the solid

\footnotetext{
${ }^{5}$ S. Biscop, J. Howorth and B. Giegerich, Europe: A Time for Strategy (Egmont Paper 27, Brussels: Academia Press for the Royal Institute for International Relations, 2009); S. Biscop (ed), The Value of Power, the Power of Values (Egmont Paper 33, Brussels: Academia Press for the Royal Institute for International Relations, 2009); A. de Vasconcelos (ed), A Strategy for EU Foreign Policy (Paris: European Union Institute for Security Studies, 2010); J. Howorth, 'The EU as a Global Actor: Grand Strategy for a Global Grand Bargain?', Journal of Common Market Studies, vol. 48, no. 3, 2010, pp. 455-74.
} 
core of material assets that would underpin any pursuit of concrete goals ${ }^{6}$ (Council 2003, 2008; Dannreuther and Peterson, 2006). Whereas the United States can be criticised for squandering its 'soft power', the EU in areas outside commercial and development policy has to base its pursuit of world order predominantly on the politics of persuasion and attraction. Whereas the United States can be criticised for placing material interests above common values in its pursuit of grand strategy, the EU can equally be faulted for having nothing but broad statements of 'European values' with which to focus its international activity. To be sure, its Member States have the interests, and some have the resources, on which to base a conventional international strategy, but to say this is of course to highlight the problem - the EU cannot reliably and consistently extract resources from or supplant the interests of its Member States. The implications for diplomatic practices at the European level are important: the lack of state authority, of 'hard power' and of a military establishment has meant that representation, communication and negotiation have been carried out on the one hand in something of a political and strategic vacuum, whilst on the other hand 'European' diplomats have had constantly to allow for the presence and often the competing activities of member state diplomatic structures.

There is of course a way of expressing this complexity and patchiness. Whereas the US can be presented as a 'warrior state', espousing a sovereignist foreign policy and diplomacy, prone to the use of hard power and inclined to pursue bilateral or even unilateral courses of action, the EU might be characterised as a 'trading state'. Such a characterisation implies a

\footnotetext{
${ }^{6}$ A Secure Europe in a Better World, Council of the EU December 2003, 2008; R. Dannreuther and J. Peterson (eds), Security Strategy and Transatlantic Relations (London: Routledge, 2006); Biscop et al, A Time For Strategy.
} 
diplomacy centred on implementation of a post-sovereign 'civilian' or 'normative' foreign policy, largely but not entirely expressed through the use of 'soft power' and channelled through multilateral negotiations or institutional engagement wherever possible ${ }^{7}$. No matter that at least occasionally the EU seems to act at least a bit like a more conventional 'power', and that its use of 'soft power' can appear distinctly 'hard edged' to those who experience it the central tendencies are clear, and clearly distinguished from those of US foreign policy and diplomatic practices.

A series of paradoxes results from this, underlining the hybridity of 'European diplomacy'. In present conditions, the EU seems fated to pursue a kind of rootless diplomacy, without the basis in concrete interests or material resources that might give it a harder core. As noted above, such a diplomacy is often characterised as 'post-sovereign', , but it exists in a global (and a European) arena where there is still plenty of 'sovereignist' diplomacy' to be found. Partly as a result of this uneasy coexistence, European diplomacy can be seen as 'process orientated' rather than 'results-orientated', since it is through the process of (preferably multilateral) engagement and negotiation that some degree of self-realisation of a collective European diplomatic entity can be observed. There is often a veneer of collective action, and of common strategy, but this veneer can be shattered all too easily when confronted with challenges from more conventional 'powers'. There is a degree of 'Brusselisation' of diplomacy, which has been underlined by the provisions of

\footnotetext{
${ }^{7}$ Smith, 'Between Two Worlds' and 'The EU, the US and Global Public Goods'. The idea of the 'trading state' was first discussed by Richard Rosecrance: R. Rosecrance, The Rise of the Trading State: Conquest in the Modern World (New York: Basic Books, 1986); see also R. Rosecrance, 'Trading States in New Concert of Europe' in $\mathrm{H}$. Haftendorn and C. Tuschhoff (eds) America and Europe in an Era of Change (Boulder, CO: Westview Press, 1993).

${ }^{8}$ R. Adler-Nissen, 'Late Sovereign Diplomacy', The Hague Journal of Diplomacy, vol. 4, no. 2, 2009, pp. 121-41.
} 
the Lisbon Treaty for a common diplomatic service (the European External Action Service) and by the development of stronger institutions for the coordination of foreign policy in general and of diplomatic activity in particular'. But the system of 'European diplomacy' remains a focus for important internal tensions, engaging a multitude of stakeholders at both national and European levels ${ }^{10}$.

\section{A European-American Diplomatic System?}

The US is the most significant 'other' of the European integration process, but at the same time, it is also part of a collective 'we' expressed in the broader structures and processes of transatlantic relations and in terms of the increasing economic integration of the North Atlantic area ${ }^{11}$. If there is an emergent European-American diplomatic system centred on EU-US relations, such a system will express the differences of diplomatic cultures and practices outlined in the earlier parts of the article, as well as the hybridity and complexity of the emerging EU diplomatic system itself. As a result, in contrast to the stark dichotomy suggested earlier between the diplomacy of the US as a 'warrior state' and the EU as a 'trading state', the EU-US diplomatic system is itself likely to be a hybrid and a challenge to assumptions of difference on both sides of the Atlantic.

\footnotetext{
${ }^{9}$ D. Allen, 'Who Speaks for Europe?' in J. Peterson and H. Sjursen (eds), A Common Foreign Policy for Europe? Competing Visions of the CFSP (London: Routledge, 1998). See also for the EEAS, S. Duke, 'Providing for European-level Diplomacy After Lisbon: The Case of the European External Action Service', The Hague Journal of Diplomacy, vol. 4, no. 2, 2009, pp. 211-33.

${ }^{10}$ B. Hocking and M. Smith, 'The Emerging Diplomatic System of the European Union: Frameworks and Issues', paper presented at the European Consortium for Political Research Standing Group on the European Union Conference, Porto, Portugal, June 2010. A revised version of the same paper was presented at the University Association for Contemporary European Studies 40 ${ }^{\text {th }}$ Annual Conference, Bruges, Belgium, September 2010.

${ }^{11}$ S. McGuire and M. Smith, The European Union and the United States: Competition and Convergence in the Global Arena (London: Routledge, 2008), chapter 2.
} 
I would argue that the European-American diplomatic system demonstrates three key sets of diplomatic processes, which are and will remain central to its development. These can be summarised as 'special relationships', 'transatlantic governance' and 'world order diplomacy'. The first of these, 'special relationships', reflects the conventional end of the diplomatic spectrum. It privileges relationships between the US and individual countries in Europe, including, of course, all members of the EU; and by doing so, it reflects the rather traditional tendencies of dominant powers to foster client relations and dependencies, and lesser powers to cluster around the dominant. The expressions of this type of relationship are diverse in form, but not necessarily in essence; they range in recent years from the ritual 'race to the White House' of European leaders at the beginning of each new US Administration to the 'shoulder to shoulder' diplomacy of the early War on Terror and the invasion of Iraq. They are the opposite, apparently, of any notion of European collective diplomacy, and they demonstrate the capacity of the US to divide and rule almost without trying. But they are not unaffected by the development of 'European diplomacy' centred on the EU. Even the most significant of the EU Member States are not immune to the shaping of their diplomacy by their involvement in the 'multi-perspectival polity' created by European integration, whilst the 'Europeanisation' of the diplomatic practices of lesser EU Member States can make a significant difference to their approach to the dominant power, for example by expanding the scope of their diplomatic involvement in general and by providing political economies of scale to cover their disagreements with US policies ${ }^{12}$.

\footnotetext{
${ }^{12}$ Spence, D. 'Taking Stock: Fifty Years of European Diplomacy' The Hague Journal of
} 
Another central element in the emerging European-American diplomatic system is that of 'transatlantic governance'. Especially in the area of transatlantic political economy and economic diplomacy, there has grown up a forest of institutions dedicated to managing transactions and the inevitable disputes between the EU and the $\mathrm{US}^{13}$. Many of these institutions fall broadly within the ambit of the Transatlantic Economic Partnership, first established in the late 1990s but given new form and direction after a German initiative in 2007. They are built upon the foundations provided during the 1990s by the Transatlantic Declaration and then the New Transatlantic Agenda ${ }^{14}$. And they have spread into broader areas of regulatory cooperation such as those involved with anti-trust and competition policy, or air transport policy, often as the result of extended EU-US commercial diplomacy ${ }^{15}$. They have been joined since 9.11 by a range of institutions and practices dedicated to counter-terrorism, and involving areas such as regulation of financial transactions, exchange of passenger information and broader police cooperation $^{16}$. Often, of course, these processes of governance are carried out by persons who would not be instantly recognised as diplomats, and whose practices are not those of conventional diplomacy, embodying as they do elements of legal and technical expertise that are not commonly found in

\footnotetext{
Diplomacy vol. 4, no.2, 2009, pp. 235-59.

${ }_{13}$ M. Pollack and G. Shaffer (eds), Transatlantic Governance in the Global Economy (Lanham, MD: Rowman and Littlefield, 2001; J. Peterson and M. Pollack (eds), Europe, America, Bush: Transatlantic Relations in the Twenty-First Century (London: Routledge, 2003); B. Steffenson, Managing EU-US Relations: Actors, Institutions and the New Transatlantic Agenda (Manchester: Manchester University Press, 2005)

${ }^{14}$ M. Pollack, 'The New Transatlantic Agenda at Ten: Reflections on an Experiment in International Governance', Journal of Common Market Studies vol. 43, no. 5, 2005, pp. 899919

${ }^{15}$ See for example C. Damro, Cooperating on Competition in Transatlantic Economic Relations (Basingstoke: Palgrave/Macmillan, 2006).

${ }^{16}$ See W. Rees, Transatlantic Counter-Terrorism Cooperation: The New Imperative (London: Routledge); W. Rees, 'The External Politics of Internal Security' in C. Hill and M. Smith (eds) International Relations and the European Union ( $2^{\text {nd }}$ edition, Oxford: Oxford University Press, 2011).
} 
foreign offices. The processes are thus sustained by networks of cooperation in which diplomats may be joined by 'domestic' officials and by nongovernmental actors, producing a form of 'intense transgovernmentalism' with added transnational elements at the transatlantic level. Their growth provides compelling evidence of the ways in which a hybrid diplomatic system already exists between the EU and the US - and it also plays to the strengths of the EU by focusing on political economy and regulatory politics rather than the 'high politics' of conventional security policies.

The third element of the EU-US diplomatic system that should be explored here is 'world order diplomacy'. This is an area in which 'European diplomacy' has received decidedly mixed notices, especially in its attempts to exercise diplomatic influence outside its own European backyard; critics have drawn attention to the slowness and deliberative nature of EU foreign policymaking, and to the ways in which European leverage declines dramatically once it moves outside areas in which it might be seen as exercising 'external governance'. This has also been noted by a series of US policy-makers, including those of both the George W. Bush and the Obama administrations, and as a result it could be argued that the EU has become progressively marginalized in US diplomacy during the post-Cold War period - even, it must be said, in some regions very close to the EU heartland, in the Balkans and the Caucasus.

A related area of tension and ambiguity in the EU-US diplomatic system, when it comes to matters of world order, centres on the availability and potential use of force. There has developed a strong differentiation between EU policies largely based on conflict prevention (and thus on the 
predominance of diplomacy and 'civilian' methods) and US policies that contemplate the use of force $a b$ initio (even if force is not actually deployed). But there is also an element of differentiation within the EU itself, where a number of Member States are more ready and able to contemplate the use of force, and where this readiness is accentuated by the demands of US diplomacy. This opens up the prospect of 'divide and rule' in EU-US diplomacy, either as the result of deliberate US tactics or as a reflection of internal tensions within the EU itself.

Such negative judgements do not, however, reflect the whole picture. The EU-US diplomatic system in relation to world order issues is not simply a case study in US dominance and European deference or marginalisation. Partly, this reflects the changing nature of 'world order issues' themselves, with the growing emphasis on global governance and institutions that has been noted by many analysts ${ }^{17}$. The EU has seemed at times to have a comparative advantage in the kinds of multilateral diplomacy that are required in areas such as the regulation of the global environment, the pursuit of international human rights and the governance of global development, arising not least out of its experience with complex issues of international governance within the Union itself. This might be compared favourably with the discomfort felt by US diplomats in situations where they are not (or no longer) the 'governors' and are faced with issues of adaptation and adjustment with which

\footnotetext{
${ }^{17}$ See for example: J. Nye and J. Donahue (eds), Governance in a Globalizing World (Washington, DC: Brookings Institution, 2000); M. Kahler and A. Lake (eds), Governance in a Global Economy: Political Authority in Transition (Princeton: Princeton University Press, 2003); A. Prakash and J, Hart (eds), Globalization and Governance (London: Routledge, 1999); A. Prakash and J, Hart (eds), Responding to Globalization (London: Routledge, 2000).
} 
they are not familiar, such as the new politics of trade and the environment ${ }^{18}$. The EU has also, with the development of its capacity for crisis management, stabilisation and reconstruction, discovered a capacity for intervention which seems to express a type of 'structural diplomacy' aimed at getting below the skin of actors in regional and other conflicts ${ }^{19}$. In such interventions, the US has often been absent, partly because they have occurred predominantly in sub-Saharan Africa, where US diplomacy has until recently been dormant; where the US has been heavily engaged, as in the Middle East, the EU has found it very difficult to develop either a collective position or an effective structural diplomacy ${ }^{20}$.

As a result of these co-existing areas of ambiguity and tension, the EUUS diplomatic system displays a number of key features. Bilateral 'special relationships' flourish alongside a growing system of transatlantic governance in which governmental and non-governmental actors interact in conditions of complex interdependence, and both are accompanied by a diplomacy of world order in which the EU is increasingly active but is frequently marginalized by considerations of US grand strategy - or marginalizes itself through actual or potential defections by Member States. Often, defection is a reflection of precisely those 'special relationships' that exist elsewhere in the EU-US

\footnotetext{
${ }^{18} \mathrm{M}$. Smith, 'The EU, the US and International Organizations: Trade Politics in the Global Political Economy', in S. Blavoukos and D. Bourantonis (eds), The EU Presence in International Organizations (London: Routledge, 2010); M. Smith, 'The EU, the US and Global Governance', in U. Wunderlich and D. Bailey (eds), The European Union and Global Governance: A Handbook (London: Routledge, 2010).

${ }^{19} \mathrm{~S}$. Keukeleire, 'The European Union as a Diplomatic Actor: Internal, Traditional and Structural Diplomacy', Diplomacy and Statecraft, vol. 14, no. 3, 2003, pp. 31-56; S. Keukeleire and J. MacNaughtan, The Foreign Policy of the European Union (Basingstoke: Palgrave, 2008); S. Keukeleire, R. Thiers and A. Justaert, 'Reappraising Diplomacy: Structural Diplomacy and the Case of the European Union', The Hague Journal of Diplomacy, vol. 4, no. 2, 2009, pp. 211-33.

${ }^{20}$ R. Youngs, Europe and the Middle East: In the Shadow of September 11 (Boulder, CO and London: Lynne Rienner, 2006).
} 
diplomatic system; it is noticeably more prevalent in areas of global security and 'high politics' than in areas of transatlantic and global governance. The system is thus hybrid, evolving and fluctuating, and reflects short-term changes in political preferences and practices as well as longer-term underlying contrasts between European and US diplomacy.

\section{Euro-American Diplomacy from Bush to Obama}

How have the challenges created by the contrasting natures of European and US diplomacy played out in recent policy developments, and how has the hybrid nature of the EU-US diplomatic system shaped diplomatic processes and outcomes? In this part of the article, I argue that the first decade of the twenty-first century displays distinct phases of EU-US diplomacy - centring on successive US Administrations and their foreign policies, but shaped in part by developments within the EU itself - and that each of these phases can be accounted for in terms of the three types of diplomatic focuses identified above: 'special relationships', transatlantic governance and world order. As a result, I argue, each US Administration has posed a specific challenge to European diplomacy and the EU has produced a specific pattern of response.

In terms of the three coexisting strands of EU-US diplomacy outlined earlier in this article, there are important implications to be drawn from the first George W. Bush Administration and its impact on European diplomacy. First, the assertiveness and the peremptory nature of US policy gave renewed salience to 'special relationships'. Some of these were of long standing, the most obvious being that between Britain and the United States; others were relatively new, for example the relationship between Poland and the United 
States. The impact of the British-American 'special relationship' was clear in the diplomacy of armed conflict, not just in Iraq but also in Afghanistan, but it also made its mark in the new diplomacy of the 'War on Terror', with its emphasis on the exchange of intelligence and the use of new instruments to contain terrorist operations and their resources. The impact of the 'special relationships' between the US and the new EU member states was perhaps more unexpected, since Poland and a number of other new Member States (who did not, let us remember, enter the EU until January 2004) had a far less substantial track record of dissent from collective EU positions; this in part accounts for French President Chirac's conclusion in 2003 that the new Member States had missed a good opportunity to keep quiet, and his resentment of Rumsfeld's ‘old/new Europe' pronouncements.

Alongside the inevitable dramas attached to the emergence or reemergence of 'special relationships', it is important to note that the diplomacy of transatlantic governance continued. There were significant new dimensions to this area of diplomacy - some of them arising from the 'War on Terror', such as those relating to financial controls or the exchange of passenger information $^{21}$ - but there were also long-established processes of cooperation in trade and related areas, now including work for example on competition policy $^{22}$. Even though the influence of unilateralism and assertive or even coercive diplomacy was felt in areas such as environmental policy or development policy, these were areas in which the diplomacy of EU-US

\footnotetext{
${ }^{21}$ Rees, Transatlantic Security Cooperation; Rees, 'The External Politics of Internal Security'. ${ }^{22}$ Damro, Cooperating on Competition Policy.
} 
relations was on a far more even keel than in the areas of 'high politics' and 'hard security' 23 .

As might be expected from the account of 'special relationships' above, the EU-US diplomacy of world order presented a picture of conflict and tensions during the first George W. Bush Administration. Most obviously, this was felt in relation to the Iraq war and the 'War on Terror'. But there was a crucial difference between the ways in which EU and US diplomacy interacted in the two domains. On Iraq, the Americans could pose a challenge that the Europeans collectively were simply unable to meet, by acting unilaterally, emphasising pre-emption rather than prevention, and calling in the 'special relationships' that were most potent among a number of EU Member States. In the 'War on Terror', on the other hand, the instruments of conflict were more diverse and less the subject of an effective US monopoly; dealing with terrorism required financial, administrative and other instruments that the Europeans were able to mobilise collectively, and on which EU-US agreement was far more efficient than a series of bilateral diplomatic processes. Even in the area of 'high politics' therefore, the European collectively had something to offer.

At the same time, the Europeans were able to muster collective will in a number of areas of global governance and thus to resist or to by-pass US opposition. Two examples must suffice: the first is the diplomacy of the International Criminal Court, where the EU on the whole stood firmly behind ratification of the Rome Statute even while the Americans were trying to encourage defections and bilateral agreements, and the second is the

\footnotetext{
${ }^{23}$ Peterson and Pollack, Europe, America, Bush.
} 
ratification of the Kyoto Protocol on greenhouse gases, where the US firmly rejected the prospect and yet the EU was able to secure the entry into force of the Protocol in the final analysis by persuading the Russians to ratify. In both of these cases, the Europeans showed an unexpected capacity to define a collective decision, to defend it against American pressures and to deploy diplomatic resources in order to achieve their objectives through processes of communication and negotiation on the ground.

The conclusions from the period of the first George W. Bush Administration, insofar as it affected EU-US diplomacy, are inevitably mixed. It is clear that the assertive, not to say confrontational nature, of US diplomacy presented a direct - if not always intentional - challenge to attempts to foster European solidarity and collective action. It is also clear that one response to the pressure was for EU Member States to develop their own diplomatic lines in relation to Washington, either in alignment with or in distinction to US diplomacy, and that this, as was to be expected, underlined the persistent strength of Member State interests in the hybrid EU diplomatic system. But it is equally clear that in areas outside the 'high politics' of armed conflict, EU solidarity was a continuing theme, and that in a number of areas the Europeans proved equal to the kinds of pressures applied by the United States. Indeed, in some of these areas, the very assertiveness and unilateralism of US diplomacy made it easier to achieve EU solidarity and to persist with a collective European diplomatic stance. At the same time, the diplomacy of transatlantic governance provided a consistent (if not untroubled) underpinning for the management of complex interdependence in the political economy of EU-US relations, and that interdependence continued 
to grow, in terms both of mutual investment and of the exchange of goods and services in the transatlantic economy

It was perhaps inevitable in this context that 'Bush II', the second George W. Bush Administration (2005-2009) would see something of a reaction against the extremes experienced in 2002-2004. Within the US itself, more conventional diplomacy made a come-back, not least through the close alignment of the State Department under Condoleezza Rice with the President himself, and increasing attention to what was termed 'transformational diplomacy' in relation to developing countries and areas of instability ${ }^{24}$. was also a greater emphasis on multilateral approaches to the handling of conflicts and the management of disputes - partly reflecting the fact that American policy had reached the limits of its resources with involvement in both Afghanistan and Iraq, and that the use of force in Iraq especially was increasingly questioned in the United States itself. Thus, in dealing with Iran's potential nuclear capacity, the approach was very different from that pursued in Iraq. Significantly, it involved the use of collective diplomacy based within the EU, operating through the 'EU-3' (Britain, France and Germany) and in turn linked to action within the United Nations to strengthen sanctions against $\operatorname{Iran}^{25}$. At the same time, the Administration made efforts to rebuild bridges with the EU collectively, most notably through the President's visit to the EU institutions in Brussels - including the first by a

\footnotetext{
${ }^{24}$ J. Vaisse, Transformational Diplomacy (Chaillot Paper 103, Paris: European Union Institute for Security Studies, 2007). It must be noted, however, that the switch to 'transformational diplomacy' did not always extend much beyond the President and the Secretary of State, and that considerable doubts about its effectiveness were expressed in the State Department. See A. Holmes, 'Where are the Civilians? How to Rebuild the U.S. Foreign Service', Foreign Affairs, vol. 89, no. 1, Jan/Feb. 2009, pp. 148-60.

${ }^{25}$ See W. Posch (ed) Iranian Challenges (Chaillot Paper 89, Paris: EU Institute for security Studies, 2006); C. Bertram, Re-Thinking Iran: from Confrontation to Cooperation (Chaillot Paper 110, Paris: EU Institute for Security Studies, 2008).
} 
serving President to the European Commission. There were increasing diplomatic efforts to engage the Europeans in post-conflict reconstruction in a number of areas, and to develop a division of labour in dealing with key aspects of the 'War on Terror'. Not surprisingly, the results of this reorientation were to be seen in a re-ordering of the key strands in EU-US diplomatic relations. By the end of 'Bush II', special relationships were less in evidence, transatlantic governance had demonstrated its continuing vitality, and world order diplomacy was conducted with more of an eye to what the Europeans might be able to contribute ${ }^{26}$.

This partial diplomatic rebuilding of the EU-US system had a paradoxical effect on EU diplomacy. It became easier to collaborate at the EU level with the Americans, and (as noted above) to work out areas in which a division of labour might be helpful; but at the same time, the 'cement' that had been provided by opposition to US policies (and which could act as a counter to the divisiveness embodied in 'special relationships') became less easy to discern. Overall, issues became easier and more susceptible to diplomatic treatment, but at the same time the grand questions of the early 2000 s faded away. In a way, and certainly from 2007 onwards, the Europeans were waiting for Bush's successor. Simultaneously, at the European level, they were waiting for an outcome to the convoluted process that produced first the Constitutional Treaty and then the Lisbon Treaty. As a result of these two trends, one in the US and the other in the EU, by 2008 anticipation was high that on the one hand there would be a new President who would privilege diplomacy, and on the other hand there would be a European Union equipped

\footnotetext{
${ }^{26}$ De Vasconcelos and Zaborowski, Friends Again?
} 
to respond diplomatically to new opportunities. 'Waiting for Obama' and 'waiting for Lisbon' were a European preoccupation during the later part of 2008 and the early part of 2009.

Barack Obama was thus the presidential candidate favoured by the overwhelming majority of European populations and by the preponderance of the European political and diplomatic elites. On the one hand, he was the 'unBush' - an antidote to the unilateralism and the confrontational diplomacy of the early 2000s, and to the uncertain drift towards partial multilateralism during the President's second term. On the other hand, and more positively, the Obama campaign promised a renewed commitment to multilateralism and by implication to a constructive relationship with the EU and its Member States. In fact, the diplomatic challenge of the Obama Presidency turned out to be as great as that posed by the Bush Presidencies, albeit in very different ways.

The reasons for this renewed challenge were four. First, although the new Administration set about building a foreign policy that gave far more prominence to international organisations generally and to multilateralism in many forms, it explicitly demanded that partners in this process should step up to the plate and accept responsibility, rather than simply letting the US take the strain. Second, and related, the Administration based its policies on a form of pragmatic realism that was designed to be adaptable to the specific challenges and opportunities confronting the US; as a result, the key driving factor was interests and opportunities as they presented themselves to Washington rather than long term or programmatic commitments to specific partners. Third - and again related - the changing structure of the world 
arena had by 2009 created new challenges to which the US would have to respond; partly these challenges were economic, but partly also they were related to a changing appreciation of the global power structure that had inescapable political and security dimensions. Fourth, the impact of the 20082009 financial crisis inevitably meant that much of the President's attention would be focused on the domestic arena, and that many external questions would be viewed through the prism of domestic politics - perhaps even more so than has been traditionally the case in US foreign policy ${ }^{27}$.

For the Europeans, granted the President they had (almost) all wanted, this was a challenging set of conditions within which to construct a diplomatic partnership. Four questions for the Europeans followed from the four aspects of US diplomacy outlined above. First, were the Europeans ready? In other words, would the EU be able to step up to the plate on key diplomatic issues and to match the US desire for new forms of multilateralism and global governance? The European answer to this question was bound to be ambiguous. On the one hand, Obama was not Bush (or at least, not 'Bush I'): but as noted above, that actually made him more difficult for many Europeans to deal with, since a knee-jerk anti-Americanism was no longer an appropriate response to demands from Washington. From the US point of view, the confusion of points of view surrounding the Lisbon Treaty as a whole, and then the ways in which the foreign policy components of the Treaty might take effect, provided evidence of something they had seen before - the Europeans engaging in intense introspection with a sign on the door saying 'do not

\footnotetext{
${ }^{27}$ See for example: A de Vasconcelos and M. Zaborowski (eds), The Obama Moment: European and American Perspectives (Paris: EU Institute for Security Studies, 2009); Leuven Centre for Global Governance Studies, The European Union, the United States and Global Governance.
} 
disturb', and proving incapable of responding to key demands and expectations $^{28}$. Once the treaty was ratified and entered into force, in late 2009, a new phase of introspection began, this time centred on the ways in which the External Action Service, the High Representative for Foreign Policy and the President of the European Council might be established and then how they might interact in the conduct of European diplomacy. The appointment of apparently low-key administrators to the posts of High Representative and President of the European Council only served to underline this suspicion. In this context, it seemed somehow logical that the Obama Administration opted out of an EU-US summit in 2010, on the grounds that there would be nothing significant on the agenda ${ }^{29}$.

The second question for the Europeans was, could they make themselves significant, or would they be marginalized? At the beginning of 2009, the usual rush of European leaders to Washington to meet the new President included the President of the Commission, as well as the (Spanish) Presidency of the Council of Ministers, and there was a mini-rush of proposals for new EU-US agreements to solidify and extend the transatlantic partnership. None of these came to anything very much, and attention for the US Administration was inexorably drawn away to areas where there were immediate challenges and an immediate call for resources, such as Iraq and Afghanistan. These were areas in which collective EU diplomacy had very little to offer, either because of a long-standing opposition to intervention (in the case of Iraq) by many Member States, or because of growing reluctance

\footnotetext{
${ }^{28}$ See for example, A. Gardner and S. Eizenstat, 'New Treaty, New Influence? Europe's Chance to Punch its Weight', Foreign Affairs vol. 89, no. 2, 2009, pp.104-19.

${ }^{29}$ For a review of this disillusionment, see G. Rachman, 'The death of the European dream', Financial Times, $18^{\text {th }}$ May 2010, p. 13.
} 
to stay involved (in the case of Afghanistan) on the part of almost all Member States. In this context, the notion of a collective European diplomatic effort was almost a contradiction in terms, and could not be backed up by reliable access to the necessary resources. As a result, although EU involvement in reconstruction efforts in Afghanistan especially was significant, the key areas of diplomacy affected NATO (because of the issues surrounding the International Stabilisation and Assistance Force) and a number of EU Member States (because of their continuing involvement in the military effort). Where US pressure and US demands were felt was most obviously in NATO, not the EU.

The third question staring the Europeans in the face was a reflection of the changing structure of the world arena. Given the emergence of new economic and political powers (and the partial re-emergence of others), could the EU establish itself as a 'pole' in the newly multipolar world, and retain the attention of the US? For the past fifteen years, the EU has worked towards a system of 'strategic partnerships' with countries such as China, India, Brazil and Russia - and of course, its first and most important 'strategic partner' is the $\mathrm{US}^{30}$. But it is open to question whether this intense diplomatic effort has actually put the EU in position to act as a key 'pole' in the new world power structure. The doubts surrounding this area were underlined by the early diplomacy of the Obama Administration, which seemed to lend substance to the idea of a 'G-2' - the US and China. For a series of economic and political

\footnotetext{
${ }^{30}$ For a review of the EU's attempts at 'strategic partnerships', see G. Grevi and A. de Vasconcelos (eds), Partnerships for Effective Multilateralism: EU Relations with Brazil, China, India and Russia (Chaillot Paper 109, Paris: EU Institute for Security Studies, 2008). Philip Stephens in the Financial Times published a series of trenchant indictments of EU positions during 2010: see for example, 'A neuralgic Europe trails petulantly in America's wake', Financial Times, $22^{\text {nd }}$ January 2010, p. 15, and 'Europe should be wary of dancing on Obama's grave', Financial Times, $15^{\text {th }}$ October 2010, p. 15.
} 
reasons, Beijing was a far more salient and immediate concern of US diplomacy than Brussels, and this was signified by the fact that Secretary of State Hillary Clinton's first overseas visit was to Asia in general and to China in particular. The Administration's proclaimed target of 're-setting' relations with major powers, starting with Russia, and of addressing itself to other major regional powers, also gave the very strong impression that Washington saw Brussels as declining in the international pecking order (a fact that was of course linked to Europe's inability to respond to earlier questions dealt with in this section $)^{31}$. Perhaps the most striking statement of this new order of priorities was the diplomacy surrounding the Copenhagen Climate Summit in December 2009, where the EU, having entered the process thinking of itself as a climate leader, was progressively marginalized by a diplomacy which saw China flexing its muscles and the US in the shape of the President arriving at a late stage to steal the show ${ }^{32}$.

The changing global power structure linked in turn with the final question that the EU had to answer: could Europe shape diplomatic solutions to the global financial crisis that would make it a credible partner for the US, and draw Washington away from its inevitable domestic preoccupations? In this area, of course, the EU does not have a single diplomatic presence; the coexistence of the European Central Bank with the central banks of those countries not members of the Euro, and the hydra-headed nature of EU external policies involving the Commission, the Member States and other EU institutions, is not a strong prima facie basis for dealing on equal terms with

\footnotetext{
${ }^{31}$ For a review of this strategic direction, see D. Dombey and G. Rachman, 'Mapped Out; America and the World', Financial Times, $3^{\text {rd }}$ June 2009, p. 11.

32 J. Vogler, 'The Challenge of the Environment, Energy and Climate Change', in C. Hill and M. Smith (eds), International Relations and the European Union ( $2^{\text {nd }}$ edition, Oxford: Oxford University Press, 2011).
} 
either Washington or the emerging powers in the world economy. During 2009 and 2010, the difficulties of agreeing on appropriate measures to combat the crisis within the EU constituted a major impediment to a European 'grand strategy' for global economic reform, culminating in the disarray within the Euro zone over the financial and economic crisis in Greece. At the same time, the emergence of the G-20 as a mechanism for global economic coordination, and the relative retreat of the $\mathrm{G}-7 / 8$, constituted at first glance a clear dilution of the EU's influence in global economic diplomacy. Whether or not this proves to be the case in the long term, the EU's status as a core global economic power and a key participant in international rule-making has come under scrutiny. Meanwhile, the US has continued to be preoccupied with its own internal economic crisis, and on the changing internal politics that go along with the mid-term elections and the misfortunes of the Obama Administration.

In terms of the three dimensions of the EU-US diplomatic system that have been at the heart of the argument, some significant developments can be discerned from this study of the Obama Administration's first two years. An immediately striking feature is that 'special relationships' have played a far less prominent role in the conduct of EU-US diplomacy since 2009 than they did under the Bush Administration. It could be argued that this retreat from 'special relationships' was under way under the second George W. Bush Administration, but it certainly accelerated once Obama entered the White House. In part this reflects the less contentious nature of EU-US relations as a whole - but it also reflects the emergence of new preoccupations for US diplomacy, in the shape of the 'BRICs' and other emerging powers. A second 
feature is that the diplomacy of transatlantic governance has remained low key and has led to the resolution (or at least the non-escalation) of a number of ongoing disputes, especially in the political economy of transatlantic relations. A final and very striking feature is that 'world order' diplomacy has seen the Europeans taking a back seat - unwillingly - as new powers have attracted the Americans' attention and as these powers have played a more active role in issues of global governance ${ }^{33}$. At the same time, the EU has been unable to respond effectively to the more demanding US requests for assistance in 'world order' issues such as those in Iraq and Afghanistan despite the fact that the voice asking for assistance is one that they wanted in the White House.

There is an obvious conclusion to this phase of the argument: that during 2009 and 2010, the Obama Administration's diplomacy, combined with a series of interrelated factors emerging from within and outside the EU, led to a relative marginalisation of European diplomacy both in relation to the US and in the broader world arena. The pragmatic realism and conditional multilateralism of the US Administration proved more demanding in some ways than the diplomacy of the George W. Bush years, dramatic as that sometimes was. Ratification and implementation of the Lisbon Treaty proved time-consuming and led to a prolonged burst of introspection in the EU. The changing global power structure led to inevitable changes of focus and when combined with the global financial crisis these diluted the capacity of the EU to respond to US diplomacy, or to shape any of the positions coming out of

\footnotetext{
${ }^{33}$ For reactions to this apparent failure of Europe to shape the agenda, see the following contributions to the Europe's World web site: P. Solbes and R. Youngs, 'Europe is failing to shape the global governance debate', http://www.europesworld.org (accessed 24.09.2010), and G. Merritt, 'Shaping Europe's global role I: Why the EU badly needs a new political narrative', http://www.europesworld.org (accessed 15.10.2010).
} 
Washington. As a result, questions arise about the future of the EU-US diplomatic system and about the future of European diplomacy.

\section{Conclusions}

The United States is central to the development of European diplomacy - and it will remain so. American diplomacy is a key shaping force in the logics that drive the creation of a 'European foreign policy', and constitutes a key presence in determining the effectiveness or ineffectiveness of EU diplomacy as well as that of the Union's Member States. Although there are strong elements of continuity in US foreign policy and diplomacy, each new Administration in Washington poses new challenges because of the ways in which successive Presidents and their foreign policy teams choose to approach and to deal with Europe. These forces in US diplomacy intersect and interact with those shaping the essentially hybrid nature of diplomacy within Europe and within the EU. As noted earlier in this article, the multiple influences on and modes of EU-US diplomacy are not reducible to a simple contrast between 'warrior states' and 'trading states', although those characterisations provide a powerful starting point for analysis. As a result of the intersection between US and European diplomacy, a hybrid and multifocal 'EU-US diplomatic system' has emerged, containing (at least) three distinct strands: the diplomacy of 'special relationships', of transatlantic governance and of world order.

The operational consequences of these coexisting modes of diplomacy are significant both for the US and for the Europeans. At one level, there is a permanent likelihood of 'divide-and-rule', with US diplomacy and 'special 
relationships' driving wedges between the Europeans. At a second level, thanks to the pressures and constraints of complex interdependence embodied in the diplomacy of transatlantic governance, there is a great deal of continuity and mutual engagement. At a third level, the diplomacy of world order in the contemporary era demonstrates features of the kind of intense bilateralism that can be seen in 'special relationships', of the kind of intense transgovernmentalism and transnationalism that is also present in transatlantic governance, and of the diplomacy of 'grand strategy' that is embodied in approaches to the changing power structure of the global arena. Within this context, the EU-US diplomatic system varies in salience, in impact and in the constraints it imposes on the parties to it. Here again, the nature of 'domestic' leaderships in the United States is a key shaping factor.

Another key factor, as I have noted at several junctures, is the nature of the European integration project, and more specifically the construction of a European Union diplomacy. This has been and remains an uncertain quantity, partly because of the uncertainties arising from the broader integration and 'European foreign policy' projects of which it is part. One of the hopes pinned on the Lisbon Treaty by Europeans, and indeed by many outside Europe including those in Washington, was that it would mark a definitive act of creation in the emergence of a European diplomacy, both through the impact of institutional changes and through the recognition on the part of Europeans that such a diplomacy was a key element in the emergence of a European identity and a European collective presence in world politics.

Such a European diplomacy cannot yet be taken for granted. One reason for this lies in the inevitable internal wrangling over the constitution of 
the European diplomatic machine, which has characterised the period since the entry into force of the Lisbon Treaty. Another reason for continued uncertainty about the future of European diplomacy lies in the challenges posed by international structure and the attitudes of significant others, the most important of which is the US. The evaluation of EU-US diplomacy carried out in this paper and covering the George W. Bush and early Obama years, indicates that US diplomacy will remain a challenge to European diplomacy in the long term, and that while different US administrations will pose their own specific and often dramatic challenges, the underlying challenge itself cannot be shirked. The EU-US diplomatic system will remain complex and hybrid in nature, generating continuing arguments about competition, convergence and divergence between European and US diplomacy, and demanding sophisticated and differentiated diplomatic responses from both sides of the Atlantic. No clearer illustration could be found of this set of demands than the impact of the 'Arab spring' and of the killing of Osama bin Laden in early 2011. Although these two episodes await detailed analysis and evaluation, it might be contended that they not only exposed the underlying differences of diplomatic and 'hard power' capacity between the EU and the US but also demonstrated in sharp form the multifocal nature of the 'EU-US diplomatic system' and the resulting tensions in the EU's emerging diplomacy. 